\title{
Reference Styles: Implications of Citation Standards
}

\section{Damini* and Prabhpreet Kaur}

Department of computer science and engineering, Guru Nanak Dev University, Amritsar, Punjab, India

Received 20 May 2018, Accepted 22 July 2018, Available online 24 July 2018, Vol.8, No.4 (July/Aug 2018)

\begin{abstract}
This paper discusses the different referencing styles. Referencing acknowledges the sources of information and ideas that you have used to write your paper and which allows the sources to be identified. This paper focuses on the different types of referencing styles you can use with examples.
\end{abstract}

Keywords: APA, MLA, Chicago, Harvard, Vancouver, IEEE style

\section{Introduction}

Referencing is used to tell the reader where ideas from other sources have been used in the paper. It gives the credits to the original author. Referencing is a formal system where you follow some rules and standards while formatting the references and citations. So it enhances the presentation of your work and shows that it is based on knowledge. Referencing has two elements: Reference List and citations. Citation indicates the which ideas taken from others and from whom so its a giving a credit to an individual for their work, whereas Reference List is a list of all the sources you have cited in your paper.All sources appearing in the list are listed in the order in which they are first cited(not alphabetically). In this way any reader can trace the sources very easily. If you do not acknowledge another person's work you could be accused of plagiarism. Therefore you should include a reference for all the sources of information that you use whether it is journal/book/website and so when writing a piece of your work. There are various referencing styles that are used but the styles which are mostly used have been covered in this paper.

Different Referencing Styles

\section{APA (American Psychological Association)}

APA is an author/date based style that is the focus is on the author and the date of a piece of a work to uniquely identify it.

It is used by Education, Psychology and Sciences.

\section{MLA (Modern Language Association)}

*Corresponding author's ORCID ID: 0000-0001-7462-1238 DOI: https://doi.org/10.14741/ijcet/v.8.4.18
It is a concise style used in the arts and humanities particularly in the USA. It is the most well used of all of the citation styles.

\section{Chicago and Turabian}

This style is generally used by the Business, History and the Fine Arts.

\section{Harvard}

Harvard is very similar to the APA so also called as author date style.Where APA is primarily used in the USA and Harvard referencing style is used in the UK and Australia and is used in the field of Humanities.

\section{Vancouver}

It is mainly used in the medical and scientific papers. IEEE (Institute for Electrical and Electronics Engineers) It helps in to publishing journals, magazines, and so

Oxford

It is a note citation system developed by the University of Oxford. It is also sometimes referred to as the documentary-note style.

\section{III.APA style}

APA (American Psychological Association)Style originated in 1929,when a group of psychologists, anthropologists, and business managers establish a simple set of procedures, or style rules to increase the ease of reading .This style consists of guidelines or rules that a publisher observes to ensure consistent presentation of written material. The APA citation style (6th Edition) is author-date style, means put the 
author's last name and the publishing date into parentheses. The APA format consists of a reference list and in-text citations .APA citations requires

- Publisher

- City and state of the publication

- Page or paragraph numbers

- Author

- Title

- Publication month, date and year

APA in-text citations includes the last author and year of publication. Page numbers are also included.

Author's contribution information and titles:

The authors who are the main contributors, are placed first in the citation. All author names are formatted by last name, followed by the first and middle initial of the author. If there is more than one author, arrange them in the same order as found in the source.

1. If there is one author-Last, First name. Middle name. 2. If there are two authors- Last, First name. Middle name., \& Last, First name. Middle name.

3. If there are three to seven authors- Last, First name. Middle name. , Last, First name. Middle name., \& Last, First name. Middle name.

4. If there are seven or more authors- Last, First name. Middle name., Last, First name. Middle name., Last, First name. Middle name., Last, First name. Middle name., Last, First name. Middle name., Last, First name. Middle name., .. . Last, First name. Middle name.

5. Author's credentials (PhD, M.D) should not be included.

Sometimes there can be contribution rather than author, such as an editor. If there is an editor but no author, place the editor's name in the author's position of the citation and add "(Ed.)" or "(Eds.)" after the last editor's name.

Editor, no author Editor, F. M., \& Editor, F. M. (Eds.). (Year). Title of work. Location: Publisher.

Examples:

\section{- Book}

APA-Author, F. M. (Year of publication). Book title: Subtitle. City, State: Publisher.

Example-Sauren, J. (2015). The fault in our stars. New York, NY: Dutton Books.

- Chapter/Anthology

APA- Author, F. M. (Year of publication). Title of chapter. In F. M. Editor (Ed.), Title of book (pp. xx-xx). Location: Publisher.

Example-Green, H. (1990). Hawthorne and his mosses. In N. Baym (Ed.), The Norton anthology of American literature (pp. 5-25). New York, NY: W. W. Norton.
- Magazine

APA-Author, F. M. (Year, month of publication). Article title. Magazine Title, Volume (Issue),pp-pp.

Example-Win5, L. (2013, June). Breaking free from addiction. Monitor on Psychology, 44(6), 30-34

- Newspaper

APA--Author, F. M. (Year, month date of publication). Article title. Newspaper title, pp. xx-xx

Example--Bowman, L. (1990, March 7). Bills target Lake Erie mussels. The Pittsburgh Press, pp. A4.

- Journal (online)

APA---Author, F. M. (Publication year). Article title. Journal title, Volume (Issue), pp.-pp. doi:xx.xxxxxOR Retrieved from journal URL

Example-Trier, J. (2007). "Cool" engagements with YouTube: Part 2. Journal of Adolescent \& Adult Literacy, 50(7), 598-603. doi:10.1598/JAAL.50.7.8

\section{Journal (print)}

APA-Author, F. M. (Publication year). Article title. Periodical title, Volume (Issue), pp.-pp.

Example--Lin, M. G., Hoffman, E. S., \& Borengasser, C. (2013). Is social media too social for class? A case study of Twitter use. TechTrends, 57 (2), 39-45.

a) Website

APA-Author, F. M. (Year, month date of publication) Article title. Retrieved from URL

Example-Limer, E. (2013, October 1). Heck yes! The first free wireless plan is finally here. Retrieved from http://gizmodo.com/heck-yes-the-first-freewirelessplan-is-finally-here-1429566597

\section{- TV/Radio Show}

AP-Writer, F. M. (Writer), \& Director, F. M. (Director) (Year of airing). Episode title [Television series episode]. In F. M. Producer (Executive producer), TV series name. City, State of original channel: Channel.

Example-Dick, L. (Writer), \& Yaitanes, G. (Director). (2009). Simple explanation [Television series episode] In P. Attanasio (Executive producer), House, M.D. Los Angeles, CA: Fox Broadcasting Company.

\section{- Film}

AP-Producer, F. M. (Producer), \& Director, F. M. (Director). (Release year). Title of motion picture [Motion picture]. Country of origin: Studio.

Example-Stiller, B. (Producer) \& Ayoade, R. (Director) (2011). Submarine [Motion picture]. United Kingdom: Film4 Productions

- Audio recording

AP-Songwriter, F. M. (Copyright year). Song title [Recorded by F. M. Last (performer's name)]. On Album title [Medium of recording].City, State of label: Record label name.

EX-Turner, A. (2013). Do I wanna know? [Recorded by Arctic Monkeys]. On AM [MP3 file]. London, England: Domino Records 
- Online lecture slides

AP-Author, F. M. (Publication year). Name or title of lecture [file format].Retrieved from URL

EX-Jacobson, T. E. \& Mackey, T. (2013). What's in a name? : Information literacy, metaliteracy, or transliteracy [PowerPoint slides]. Retrieved from http://www.slideshare.net/tmackey/acrl-2013

\section{- Thesis/dissertation}

AP-Author, F. M. (Publication year). Title of dissertation/thesis (Doctoral dissertation or Master's thesis). Retrieved from Name of database. (Accession or Order No.)

EX-Knight, K. A. (2011). Media epidemics: Viral structures in literature and new media (Doctoral dissertation). Retrieved from MLA International Bibliography database. (Accession No. 2013420395)

\section{MLA Style}

MLA is a Modern Language Association style widely used in the humanities and literature. The current format is in its 8th edition and was developed by the Modern Languages Association. The MLA format consists of-

Author

Title of Source

Container

Other Contributors

Version

Number

Publisher

Publication Date

Location

These elements are ordered in such a way as they will ordered in the citation.

Its terminology consists of the core elements, source and containers. Core Elements are consists of the facts common to most works whereas the work you site is always called the source but when that work is also a part of larger whole then the larger work is called the container. Assuming example of citing a chapter from the book, then the chapter is the source and the book is the container. The basic examples are given in the following table:

\begin{tabular}{|l|c|}
\hline Source & Container \\
\hline Article & Magazine or Newspaper \\
\hline Article & Journal \\
\hline Article & Blog \\
\hline Book, Online & Database \\
\hline
\end{tabular}

\section{MLA in-text citations}

The MLA format is simpler than other referencing styles as it was developed to give the clarity. The style uses a two-part documentation system for citing sources: parenthetical or in-text citations is in the author-page format that are keyed to an alphabetically ordered works cited page. This means that the author's last name and the page number from which the

General Format: Assuming an article in the magazine or journal.

Table of core elements

\begin{tabular}{|c|c|}
\hline Author & D. Shakthi Prasad ; B. Subba Reddy \\
\hline Title of source & $\begin{array}{c}\text { IEEE transactions on Industry } \\
\text { Applications }\end{array}$ \\
\hline Title of journal & $\begin{array}{c}\text { Study on Corona Activity using Image } \\
\text { Processing }\end{array}$ \\
\hline Number & Volume: 53, no: 4 \\
\hline Date & 12 April 2017 \\
\hline Location & DOI: $10.1109 /$ TIA.2017.2693360 \\
\hline
\end{tabular}

Example:

Published in: IEEE Transactions on Industry Applications (Volume: 53, Issue: 4, July-Aug. 2017) DOI is Digital Object Identifier which is the unique and permanent identifying number.CrossRef.org makes DOI's easy to find. It is free DOI lookup.

Figure shows the flowchart of the DOI and URL. Try to include DOI for every reference

The official MLA style center website available at https://style.mla.org/

Following are the popular examples for MLA Style:

A. Book

Order: author, book title, city of publication, publisher name, year, page number (optional).

1. Mason,The River:Land of rivers (Wellington: Hola Publishers, 2003), 22.

B. Chapter in an edited book

Order: author, chapter title, book title, editors, page range, city of publication, publisher name, year, page number (optional).

2. Ash Amin, "The Economic Base of Contemporary Cities," in A Companion to the City, ed. Gary Bridge and Sophie Watson, 115-129 (Oxford: Blackwell, 2000), 120.

C. Journal article

Order: author, article title, journal title, volume number, issue number, year, page number (or page range, in bibliography).

3. Francis G. Castles, Jennifer Curtin, and Jack Vowles, "Public Policy in Australia and New Zealand: The New Global Context," Australian Journal of Political Science 41, no. 2 (2006): 135.

D. Web page

Order: author, page title, site owner, URL.

4. A. Benson, "Potamopyrgus antipodarum," United States Geological Survey, http://nas.er.usgs.gov/ queries/FactSheet.asp?SpeciesID=1008.

\section{Chicago}

Chicago is a style that has been published by the Chicago University Press since 1906. This citation style 
incorporates rules of grammar and punctuation common in American English. Chicago style presents two basic documentation systems: (1) notes and bibliography and (2) author-date. Choosing between the two often depends on subject matter and the nature of sources cited, as each system is favored by different groups of scholars. There are two styles of referencing in the Chicago Manual of Style, 16th edition. The notes and bibliography is preferred by many in the humanities, literature, history, and the arts.

Notes: Consecutively numbered markers in the text refer the reader to bibliographic citations in footnotes or endnotes.

Bibliography: A bibliography at the end of the document provides full details of all sources cited and consulted by the writer.

Chicago citations require:

- Author

- Title of book/article

- Title of newspaper/journal

- Publication year

- Publication month and date

- Publisher

- City of publication

- Date of access

- Page numbers

- URL or doi (for some online sources)

Author's contribution information and titles:

The Chicago Manual of Style details author formatting for both footnotes and reference pages.

1. One author Last, First M.

2. Two or more authors Last, First M., and First M. Last.

3. More than 10 authors List the first seven authors, followed by et al.

4. Authors who use initials in their first names (e.g., J.K. Rowling, C.S. Lewis), add a space between their initials. Example-Salinger, J. D. The Catcher in the Rye. Boston: Little, Brown, 1951.

5. Editors, Translators, Compilers

For works with an editor/translator/compiler and no author, list the contributor's name, followed by ed. /eds., comp. /comps. Or trans. after the contributor(s) last name(s), preceded by a comma.

One editor Last, First M., Ed.

Two translators Last, First M., and First M. Last, trans.

6.For works with authors and additional contributors such as an article in an edited anthology - list the author's name first. After the article title, list the additional contributor names, preceded by Edited by , Compiled by , Translated by or Ed., Comp., or Trans.

7.If a work has an editor and a translator, list them in the same order as they appear on the title page. If the author is unknown, begin the citation with the title.

\begin{tabular}{|c|c|}
\hline $\begin{array}{c}\text { Material } \\
\text { Type }\end{array}$ & Notes/Bibliography Style \\
\hline $\begin{array}{l}\text { A book in } \\
\text { print }\end{array}$ & $\begin{array}{c}\text { Note Style: 1. Michael Pollan, The Omnivore's } \\
\text { Dilemma: A Natural History of Four Meals (New } \\
\text { York: Penguin, 2006), 99-100. } \\
\text { Duplicate Note: 2. Pollan, Omnivore's Dilemma, } 3 . \\
\text { Bibliography: Pollan, Michael. The Omnivore's } \\
\text { Dilemma: A Natural History of Four Meals. New } \\
\text { York: Penguin, 2006. }\end{array}$ \\
\hline $\begin{array}{c}\text { An article } \\
\text { in a print } \\
\text { journal }\end{array}$ & $\begin{array}{c}\text { Note Style: 1. Joshua I. Weinstein, "The Market in } \\
\text { Plato's Republic," Classical Philology } 104 \text { (2009): } \\
440 . \\
\text { Duplicate Note: } 2 . \text { Weinstein, "Plato's Republic," } \\
452-53 . \\
\text { Bibliography: Weinstein, Joshua I. "The Market in } \\
\text { Plato's Republic." Classical Philology } 104 \text { (2009): } \\
439-58 .\end{array}$ \\
\hline $\begin{array}{l}\text { An article } \\
\text { in an } \\
\text { electronic } \\
\text { journal }\end{array}$ & $\begin{array}{c}\frac{\text { Note Style: 1. Gueorgi Kossinets and Duncan I. }}{\text { Watts, "Origins of Homophily in an Evolving Social }} \\
\frac{\text { Network," American Journal of Sociology } 115}{(2009): 411 \text {, accessed February 28, 2010. }} \\
\text { doi:10.1086/599247. } \\
\frac{\text { Duplicate Note: Kossinets and Watts, "Origins of }}{\text { Homophily," 439. }} \\
\text { Bibliography: Kossinets, Gueorgi, and Duncan I. } \\
\frac{\text { Watts. "Origins of Homophily in an Evolving Social }}{\text { Network." American Journal of Sociology 115 }} \\
\frac{(2009): 405-50 . \text { Accessed February 28, 2010. }}{\text { doi:10.1086/599247. }}\end{array}$ \\
\hline A website & 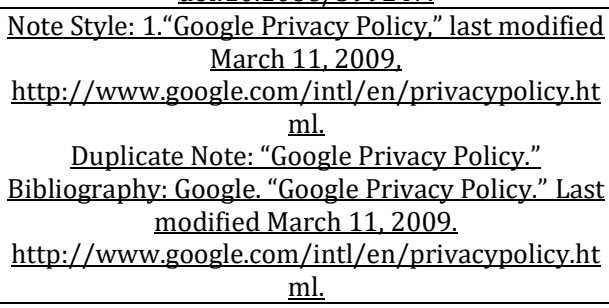 \\
\hline
\end{tabular}

The author-date style has long been used by those in the physical, natural, and social sciences. In this system, sources are briefly cited in the text, usually in parentheses, by author's last name and date of publication. The short citations are amplified in a list of references, where full bibliographic information is provided.

\begin{tabular}{|c|c|c|}
\hline $\begin{array}{c}\text { Author/Date } \\
\text { Style }\end{array}$ & In-text Citation & Bibliography \\
\hline A book & $\begin{array}{l}\text { (Pollan 2006, } \\
\text { 99-100) }\end{array}$ & $\begin{array}{l}\text { Pollan, Michael. 2006. The } \\
\text { Omnivore's Dilemma: A } \\
\text { Natural History of Four } \\
\text { Meals. New York: } \\
\text { Penguin. }\end{array}$ \\
\hline $\begin{array}{c}\text { An article in a } \\
\text { print journal }\end{array}$ & $\begin{array}{l}\text { (Weinstein } \\
2009,440 \text { ) }\end{array}$ & $\begin{array}{c}\text { Weinstein, Joshua I. } 2009 . \\
\text { "The Market in Plato's } \\
\text { Republic." Classical } \\
\text { Philology 104:439-58 }\end{array}$ \\
\hline $\begin{array}{c}\text { An article in an } \\
\text { electronic } \\
\text { journal }\end{array}$ & $\begin{array}{l}\text { (Kossinets and } \\
\text { Watts 2009, } \\
411 \text { ) }\end{array}$ & $\begin{array}{l}\text { Kossinets, Gueorgi, and } \\
\text { Duncan J. Watts. } 2009 . \\
\text { “Origins of Homophily in } \\
\text { an Evolving Social } \\
\text { Network." American } \\
\text { Journal of Sociology } \\
\text { 115:405-50. Accessed } \\
\text { February 28, 2010. } \\
\text { doi:10.1086/599247. }\end{array}$ \\
\hline A website & (Google 2009) & $\begin{array}{c}\text { Google. 2009. "Google } \\
\text { Privacy Policy." Last } \\
\text { modified March } 11 . \\
\text { http://www.google.com/ } \\
\text { intl/en/privacypolicy.ht } \\
\text { ml } \\
\end{array}$ \\
\hline
\end{tabular}




\section{Harvard}

Harvard Referencing Style uses in-text citations for author-date. In this way, APA style is a type of Harvard referencing. The Harvard citation style is a system that writers can include other person's ideas in their work.

There are two main components:

1. In-text citations including the author's surname and the year of publication should be shown in brackets wherever another source has contributed to your work 2. A reference list gives all of the sources directly cited in your work

\section{In-text citations}

Harvard in-text citations are nearly identical to APA citations but do not put a comma between the author(s) and year of publication:

...common at the time (Jones 2005).

Like APA, direct quotations must be accompanied by page numbers:

...without a doubt" (Jones 2005, p. 22).

Like APA, secondary sources (works cited inside other works) use both authors' names:

...some uncertainty" (Nguyen, cited in Jones 2005, p. 22).

\section{Reference list}

The individual parts of a reference list entry (title, place of publication, etc.) are separated with a comma. As in APA, entries are alphabetised according to author.

Book

Order: author, year, book title, publisher, place of publication.

Wallace, A, Schirato, T, \& Bright, P 1999, Beginning university: Thinking, researching and writing for success, Allen \& Unwin, St Leonards, NSW.

\section{Chapter in an edited book}

Order: author, year, chapter title, editors, book title, publisher, place of publication.

Amin, A 2000, 'The economic base of contemporary cities', in G Bridge \& S Watson (eds), A companion to the city, Blackwell, Oxford.

Journal article

Order: author, year, article title, journal title, volume and/or issue number, page range.

Castles, FG, Curtin, JC, \& Vowles, J 2006, 'Public policy in Australia and New Zealand: The new global context', Australian Journal of Political Science, Vol. 41, no. 2, pp. 131-143.

Web page

Order: author, year, document title, site controller/sponsor, location of controller/sponsor, date of viewing, URL address.

Benson, A 2006, Potamopyrgus antipodarum, United States Geological Survey, USA, viewed 5 August 2006, <http://nas.er.usgs.gov/queries/FactSheet.asp?Species ID $=1008>$

\section{Vancouver}

The Vancouver style is a widely used numbered system of referencing or bibliographic citation. It follows rules established by the International committee of Medical Journal Editors. It consists of following:

- citations to someone else work in the text, indicated by the use of a number

- a sequentially numbered reference list at the end of the document providing full details of the corresponding in-text reference

The basic elements in the Vancouver style are:

Author(s) name(s), Title of article, Title of journal, Year of publication, Volume number ,Issue number, Page numbers (first and last) Capitalization the Vancouver style is very specific. The following general rules apply:

- Book titles -

Capitalize the first letter of the first word of the title, and the first letter of the first word after a colon.

Example:

Ageing and aged care in Australia

- Journal and newspaper titles -

Capitalize first letter of each word use the appropriate abbreviation for journal names

e.g.

D Edu Psychol

- Article, chapter or section titles -

Capitalize only the first letter of the first word, and the first letter of the first word after a colon.

e.g.

Personal resilience as a strategy for surviving and thriving in the face of workplace adversity: A literature review.

\section{IEEE}

IEEE (Institute for Electrical and Electronics Engineers): It is an institute or professional organization supporting branches like engineering, computer science, and information technology and makes many standards for a variety of industries. It also helps in to publishing journals, magazines, and so. .IEEE citation style includes in-text citations, the references should be numbered in square brackets, which refer to the full citation listed in the reference list at the end of the paper and appear in the order they appear in the text .The reference list is organized numerically, not alphabetically. It includes three features:

1.Firstly, the author name is first name (or initial) and last. This is little different from MLA style where author's last name is first.

2.Then, the title of an article (or chapter, conference paper, patent etc.) is in quotation marks. 
3. And the title of the journal or book is in italics.

a) In-text references the references are numbered [5] in the order of appearance in the article.

b) A reference list, displayed at the end of the article which provides full details of all references cited in-text.

\begin{tabular}{|c|c|c|}
\hline Type & Format & Example \\
\hline $\begin{array}{c}\text { Print } \\
\text { References }\end{array}$ & $\begin{array}{c}\text { Author(s). } \\
\text { Book title } \\
\text {. Location: Publishing } \\
\text { company, year, pp. }\end{array}$ & $\begin{array}{l}\text { B. Klaus and P. Horn, } \\
\text { Robot Vision. } \\
\text { Cambridge, MA: MIT } \\
\text { Press, } 1986\end{array}$ \\
\hline $\begin{array}{c}\text { Book } \\
\text { Chapters }\end{array}$ & $\begin{array}{c}\text { Author(s). "Chapter } \\
\text { title" in } \\
\text { Book title } \\
\text {, edition, volume. } \\
\text { Editors name, Ed. } \\
\text { Publishing } \\
\text { location: Publishing } \\
\text { company, year, pp. }\end{array}$ & $\begin{array}{l}\text { J.E. Bourne. "Synthetic } \\
\text { structure of industrial } \\
\text { plastics," in } \\
\text { Plastics } \\
\text {,2 } \\
\text { 2nd ed., vol. 3. J. } \\
\text { Peters, Ed. New York: } \\
\text { McGraw-Hill, 1964, } \\
\text { pp.15-67. }\end{array}$ \\
\hline $\begin{array}{c}\text { Article in a } \\
\text { Journal }\end{array}$ & $\begin{array}{c}\text { Author(s). "Article } \\
\text { title } \\
\text { ". Journal title } \\
\text {, vol., pp, date. }\end{array}$ & $\begin{array}{c}\text { J. U. Duncombe, } \\
\text { "Infrared navigation - } \\
\text { Part I: An assessment } \\
\text { of feasability," IEEE } \\
\text { Trans. Electron. } \\
\text { Devices, vol. ED-11, pp. } \\
\text { 34-39, Jan. 1959. }\end{array}$ \\
\hline $\begin{array}{l}\text { Articles from } \\
\text { Conference } \\
\text { Proceedings } \\
\text { (published) }\end{array}$ & $\begin{array}{c}\text { Author(s). "Article } \\
\text { title." } \\
\text { Conference } \\
\text { proceedings } \\
\text {, year, pp. }\end{array}$ & $\begin{array}{l}\text { D.B. Payne and H.G. } \\
\text { Gunhold. "Digital } \\
\text { sundials and } \\
\text { broadband } \\
\text { technology," in } \\
\text { Proc. } \\
\text { IOOC-ECOC } \\
\text {,1986, pp. 557-998. }\end{array}$ \\
\hline $\begin{array}{c}\text { Papers } \\
\text { Presented at } \\
\text { Conferences } \\
\text { (unpublished } \\
\text { ) }\end{array}$ & $\begin{array}{c}\text { Author(s). "Paper's } \\
\text { title," } \\
\text { Conference name, } \\
\text { Location, year. }\end{array}$ & $\begin{array}{l}\text { B. Brandli and M. Dick. } \\
\text { "Engineering na } \\
\text { mes and concepts," } \\
\text { presented at the } 2 \\
\text { nd } \\
\text { Int. } \\
\text { Conf. Engineering } \\
\text { Education, Frankfurt, } \\
\text { Germany, 1999. }\end{array}$ \\
\hline $\begin{array}{c}\text { Standards/P } \\
\text { atents }\end{array}$ & $\begin{array}{l}\text { Author(s)/Inventor(s } \\
\text { ). "Name/Title." } \\
\text { Country } \\
\text { where patent is } \\
\text { registered. Patent } \\
\text { number, } \\
\text { date. }\end{array}$ & $\begin{array}{c}\text { E.E. Rebecca. } \\
\text { "Alternating current } \\
\text { fed power supply." U.S. } \\
\text { Patent } 7897 \text { 777, Nov. } \\
3, \\
1987 .\end{array}$ \\
\hline
\end{tabular}

\section{Oxford}

The Oxford referencing style is a note citation system developed by the University of Oxford. It is also sometimes referred to as the documentary-note style. And it is a note citation system. It consists of two elements:

\section{- Footnote Citation \\ - Reference List}

Footnote Citation: To create the footnotes, first indicate a reference by putting a superscript number directly following the source material, this number is called the note identifier. You follow this up with a footnote citation at the bottom of the page. The note identifier often known as an in-text citation. The footnote should have the same number, to ensuring the reader knows which source the note identifier is referring to. The footnotes and note identifiers should be in numerical and chronological order. The same number should be attached to the beginning of the citation and that should be listed in chronological order. Example: Footnote example: ${ }^{1}$ Stella Cottrell, The Study Skills Handbook (Basingstoke: Palgrave Macmillan, 2013). In-text example: The sky is blue. ${ }^{1}$

For the reference list, include the names of the authors, title and date of publication, the name of the publisher and place of publication. Remember to list all the sources 㯖 referenced in the footnotes, as well as any other sources that informed your work.

Example: Cottrell, Stella, The Study Skills Handbook (Basingstoke: Palgrave Macmillan, 2013)

\begin{tabular}{|c|c|c|}
\hline Type & Footnote Example & Reference list example \\
\hline $\begin{array}{c}\text { Book: } \\
\text { Chapter } \\
\text { or Article } \\
\text { in Edited } \\
\text { Book }\end{array}$ & $\begin{array}{l}\text { 1 J. Baker, 'The Place of } \\
\text { Science and } \\
\text { Technology in the } \\
\text { Wise Management of } \\
\text { the Great Barrier Reef', } \\
\text { in E. Wolanski (ed.), } \\
\text { Oceanographic } \\
\text { Processes of Coral } \\
\text { Reefs: Physical and } \\
\text { Biological Links in the } \\
\text { Great Barrier Reef, } \\
\text { Boca Raton, CRC Press, } \\
\text { 2001, p. } 15 .\end{array}$ & $\begin{array}{c}\text { Baker, J., 'The Place of } \\
\text { Science and Technology } \\
\text { in the Wise Management } \\
\text { of the Great Barrier Reef', } \\
\text { in E. Wolanski, (ed.), Ocea } \\
\text { nographic Processes of } \\
\text { Coral Reefs: Physical and } \\
\text { Biological Links in the } \\
\text { Great Barrier Reef, Boca } \\
\text { Raton, CRC Press, 2001, } \\
\text { pp. 14-20. }\end{array}$ \\
\hline $\begin{array}{l}\text { Journal } \\
\text { Article: } 2 \\
\text { or } 3 \\
\text { authors ( } \\
\text { print) }\end{array}$ & $\begin{array}{c}1 \text { P. Addo and N. } \\
\text { Besnier, 'When Gifts } \\
\text { Become Commodities: } \\
\text { Pawnshops, Valuables, } \\
\text { and Shame in Tonga } \\
\text { and the Tongan } \\
\text { Diaspora', Journal of } \\
\text { the Royal } \\
\text { Anthropological } \\
\text { Institute, vol. 14, no. 1, } \\
\text { 2008, p. } 39 .\end{array}$ & $\begin{array}{l}\text { Addo, P. and N. Besnier, } \\
\text { 'When Gifts Become } \\
\text { Commodities: } \\
\text { Pawnshops, Valuables, } \\
\text { and Shame in Tonga and } \\
\text { the Tongan Diaspora', } \\
\text { Journal of the Royal } \\
\text { Anthropological Institute, } \\
\text { vol. 14, no. 1, 2008, pp. } \\
\text { 39-50. }\end{array}$ \\
\hline $\begin{array}{l}\text { Newspap } \\
\text { er } \\
\text { article: } \\
\text { print } \\
\end{array}$ & $\begin{array}{l}1 \text { R. Boyd, 'The City of } \\
\text { Sordid Splendour', } \\
\text { Australian, } 26 \text { August } \\
\text { 1964, p. } 10 .\end{array}$ & $\begin{array}{l}\text { Boyd, R., 'The City of } \\
\text { Sordid Splendour', } \\
\text { Australian, } 26 \text { August } \\
\text { 1964, p. } 10 .\end{array}$ \\
\hline Thesis & $\begin{array}{c}\text { 1 C. Maslem, } \\
\text { 'Melancholic } \\
\text { Identification and } \\
\text { Nostalgic Fantasy in } \\
\text { the Novels of Jean } \\
\text { Rhys', PhD Thesis, } \\
\text { University of Western } \\
\text { Australia, 2005, p. } 55 .\end{array}$ & $\begin{array}{l}\text { Malsem, C., 'Melancholic } \\
\text { Identification and } \\
\text { Nostalgic Fantasy in the } \\
\text { Novels of Jean Rhys', PhD } \\
\text { Thesis, University of } \\
\text { Western Australia, } 2005 .\end{array}$ \\
\hline
\end{tabular}

\section{Conclusions}

This paper discusses the various references and in-text citation styles used to make the reference list and bibliography consistent and easy to read different papers. Every style has its own importance in different fields some are used by Education or Psychology field 
while others could belong to Business, Art and Humanities. Thus the reference style is selected accordingly and as per suggested by your guide and mentor.

\section{References}

Agrawal A. (2009) Introduction to Reference, Bibliography, and Citation. In:EndNote 1-2-3 Easy!.Springer, Boston,MA

Woodrow L. (2014) Academic Style. In: Writing about Quantitative Research in Applied Linguistics. Palgrave Macmillan, London
Burbules N.C. (2014) The Paradigmatic Differences Between Name/Date and Footnote Styles of Citation. In: Smeyers P., Depaepe M. (eds) Educational Research: Material Culture and Its Representation. Educational Research, vol 8. Springer, Cham

Mohta A., Mohta M. (2017) References. In: Parija S., Kate V. (eds) Writing and Publishing a Scientific Research Paper. Springer, Singapore

International Review of Applied Linguistics in Language Teaching, ISSN (Online) 1613-4141, ISSN (Print) 0019 042X, DOI: https://doi.org/10.1515/iral.2003.012.

American Psychological Association (2010).Publication manual of the American Psychological Association (6 $6^{\text {th }}$ ad. $2^{\text {nd }}$ printing). Washington, DC: APA 